\title{
Research of Enterprise Groups and Centralized Financial Management
}

\author{
Haiwen Long ${ }^{1,2}$, Ou Liu $^{3}$ \\ ${ }^{1}$ Oxbridge College, Kunming University of Science and Technology, Kunming, 650106 \\ ${ }^{2}$ School of Economics, Yunnan University, Kunming, 650091 \\ ${ }^{3}$ The College of Arts and Science, Yunnan Normal University, Kunming, 651701
}

\section{KEYWORDS: Centralized Financial Management; Financial Security}

\begin{abstract}
From the 21st century, a large number of the company using the company establish a financial center, centralized management of all the company's financial settlement, the company's financial centralization, the company's financial management framework and the traditional financial framework has undergone a qualitative change. From this perspective, effective financial management, as well as the corporate governance structure, is the basis for efficient operations. Effective corporate governance structure as an institution and designed to ensure scientific decision-making enterprises; and financial management, but as an important mechanism for operation under this arrangement and design, help companies guard against operational risks, reduce the company's financial risk, reasonable ensure business objectives and relevant laws and regulations to give effective follow, but also help improve the corporate governance structure. Understanding the nature of property funds from highly centralized management of corporate governance, establish and improve the system of financial control, but also on the existing business of the company is important.
\end{abstract}

\section{Introduction}

Enterprise Group is a multi-corporate consortium, within the group to join the capital as the basic link. Enterprise Group itself is not a legal person, does not have a legal personality, it is more than corporate enterprises to more capital as the basic legal links Commonwealth ties posed. In the legal sense, corporate members of the Group companies are equal and mutually independent legal, equal and mutually beneficial economic relations between them, not on the lower administrative relations.

Enterprise Group has a huge scale. Most large-scale enterprise groups and even some large multinational corporations can be "wealthy" to describe. Data was recorded, the Department of Japanese financial conglomerate's total assets in 1990 (not including banks and insurance companies) to 102.7 trillion yen, accounting for $13.7 \%$ of the whole industry assets; capital of 5.3 trillion yen, or about $15.71 \%$ of the whole industry; sales of 211.3 trillion yen, $15.7 \%$ of the total industry. Large scale enterprise groups are evident.

It has a multi-level structure. Different members of the Group business enterprise are by the tightness of the joint assets, showing the form of a multi-level structure. Generally considered to constitute Enterprise Group member companies has three levels, they are: the core layer, usually consists of a core enterprise structure, but also constituted by a plurality of core business, such as the six major Japanese conglomerate is the case, is the core of the enterprise parent and holding companies enterprise Group, has investment centers and strategic functions of the center; close layer, the core layer is mainly composed of the Group of companies owned subsidiary; affiliates 
layer is mainly composed of the core layer and the close of business shares of the member companies . Enterprise Group is the parent company as the main body, so from this perspective that the multi-level structure of the enterprise group and the performance of the parent company, a subsidiary of Sun Company ...... and a series of multi-level structure, there are two small business groups , three, amounted to more than six or seven.

\section{The Basic Guidance of Enterprise Group}

First, achieve the internalization of market transactions, in order to reduce transaction costs. In the market-oriented modern society, the enterprise market in the interests of social division of labor and cooperation, but also to the enterprise $\mathrm{J}$ 'transaction costs. Procurement of raw materials companies, selling products or services, and financial intermediation, etc., there are many processes the transaction negotiations. This external negotiations of the transaction, for example, companies are often very strenuous country that there are two sizable petrochemical companies A and B, A, a master of playing a major product is the main raw material products day. Although they are only a few kilometers apart, but each is completely independent and does not belong to a system of enterprises, it is often due to excessive considering leaving both buying and selling from their own immediate interests can not be successfully achieved: A business when the market price of the product when dagger rose, a business will be more products sold at a higher price elsewhere, so that supply of raw materials B companies could not be guaranteed; on the contrary, when the a company's product market prices, Firm B a likely than other companies from this behavior characteristics cheaper prices of raw materials purchasing companies should not be blamed, but should be encouraged, because it is theoretically contribute to the promotion of social labor productivity Yao 161. in the long term process, the 1980s and 'the B sides are likely to be detrimental. That transaction costs on both sides, increased plant

A second full play to this tangible and intangible resources companies have the potential tangible and intangible resources of the enterprise already has, may play a role because of its scope is too narrow and a waste. If you often have a capacity for managers only manage assets of a smaller dishes (for example, one million children less) businesses, they are not full of energy; assuming that they have the ability to manage a complete asset size is large enough ( for example, 10 billion yuan in! _) business, then the business from small to large process. their energy was' to get more and more enterprises fully released intangible resources and many other aspects, such as the corporate brand it do not need to add anything you can use to extend over a new product, and thus play its role in the larger scope

Third, improve the overall competitiveness and risk-resisting ability of the Group itself is a basis for the development of a diversified According to statistics, the United States after entering the business in the 1980s, more than $80 \%$ of large companies have embarked on a more child investment, diversification, diversification of the road in both theory and practice, a wide range of basic benefit is spread business: companies may not be able to bring a higher average profit margin, but it can provide a more stable profit margins; or, through diversification, volatility may be better to avoid asking profitability for the year, so that corporate financial performance was more mature and stable.

\section{Centralized Financial Management Principles}

Centralization and Decentralization are two basic groups of modern enterprise management mode. Generally speaking, if the administration complex, it scattered layout managers the ability to control 
their own weak, should use centralized type management, and vice versa should adopt Decentralizing management. But decentralization and centralization is not absolute, in practical work must be combined with their own conditions to select the appropriate mode of management. Enterprise Group in China is through the establishment of modern enterprise system reform, most of the capital as a link to establish the parent-subsidiary system. According to the actual needs and the development of corporate strategy enterprise group management, to take a combination of centralization and decentralization of financial centralized management model more in line with the present stage of development of enterprise groups. Namely Enterprise Group's financial policy, the development of economic indicators, foreign investment and economic guarantees, financial resources management, etc., all the unified leadership of the Finance Department by the parent company, to develop a unified policy, in order to maintain the consistency of enterprise group financial policies. At the same time, in order to mobilize the enthusiasm of the subsidiary's business and its proper separation of powers, giving it full autonomy to manage, but its fund management scheduling rights, the right to dispose of assets, the right investment, income distribution and financial rights of the person in charge right to appoint and dismiss still the unified management of the parent company.

In order to achieve the enterprise management system within the Group effective coordination and control, centralization and decentralization to implement a combination of ideas, enterprise groups should be established in line with their actual production and operation of "unified leadership and decentralized management" centralized financial management system within the enterprise. According to the principle of financial authority and powers and other relatively rational division of rights and responsibilities of all levels of the financial sector, on the basis of reasonable Decentralized centralization, straighten out the relationship between financial levels, and clarify the points, should bear responsibility for the subsidiary, It should have the right to promote it all diligence, coordination, and ultimately maximize the overall economic benefits of the enterprise Group.

Choosing the right management means management, and streamline the system, we also need to take the appropriate means to safeguard the financial management in order to truly mobilize the enthusiasm of the production and operation, to achieve maximum economic efficiency of enterprises groups. Thus, according to the combination of centralization and decentralization of financial management, enterprise groups should adopt appropriate financial centralized management tools, emphasizing centralization and continue to strengthen financial supervision on the basis of appropriate separation of powers, in order to mobilize sub, enthusiasm and initiative of the subsidiary's business and consciously self-development goals and development goals of enterprise groups unite to ensure overall economic efficiency.

\section{The Affect of Corporate Governance Structure on Financial Centralized Management of Funds}

Joint-stock reform of state-owned enterprises also is in full swing, corporate governance structure in line with the modern enterprise system is gradually taking shape, a lot of state-owned enterprise group, as SASAC authorized to operate state-owned assets operation institution, on behalf of the Government to exercise the corresponding state-owned assets major decisions, return on assets, select managers and other funders interests. Also it pointed out that this interest is the shareholders' rights, specific performance: "the management of assets and management of personnel affairs combined." "The management of assets" is to perform the responsibilities of investor according to law, strengthen the capital investment, operations, revenue management; "the people," is in 
accordance with the requirements of establishing a modern enterprise system, standardize the rights of shareholders, board of supervisors and operators and responsibilities, establish a market-oriented, professional and specialized appointment of directors and managers of SOEs selection and appointment mechanism and incentive and restraint mechanisms; "steward" is legally entitled to "significant decision-making power", "significant decision-making power" in the company included in the financial decision-making program approval, cash flow management and monitoring. For subsidiaries, the indirect management must be carried out within the framework of corporate governance, while not directly intervene.

Restructuring state-owned company at the same time, many of China's private enterprises are also stepping up their own company in the leather, as with its state-owned enterprise group facing the same problem. It requires centralized fund management company business is very urgent, to a certain extent, even more than the state-owned enterprise group.

In the corresponding assets of the Enterprise Group to exercise significant decisions, return on assets, select managers and other funders interests and rights of shareholders specific performance remains: "the management of assets and management of personnel affairs combined." Enterprise Group's investor should fulfill the responsibilities of investor according to the law, which should strengthen the capital investment, operations, revenue management; enterprise company shall establish a modern enterprise system, standardize the shareholders, board of supervisors and operators rights and responsibilities, the establishment of market-oriented, professional and specialized appointment of directors and corporate managers selection and appointment mechanism and incentive and restraint mechanisms; while the operators are legally entitled to "significant decision-making power" in the company "significant decision-making power." still including the financial decision-making program approval, cash flow management and monitoring. So gradually establish and improve the Group's centralized fund management system, will have a multiplier effect on the establishment and improvement of corporate governance structure of the Group of the modern enterprise system in.

\section{Conclusion}

The arrival of the Internet age, become more centralized financial management, financial information because the network is a lot more, faster, more efficient transmission and provide technical support. But it must be noted that we are talking about any trend, we can not go to extremes. This article talking about this industry just goes to show, from the general trend in the trade-offs among the centralization and decentralization in the future will be more inclined to centralization, but that does not mean one hundred percent towards centralization, because even if the application of network technology, but also impossible to completely eliminate all the factors that led to the decentralization of the pre-pay.

\section{Reference:}

[1] COSO, 1992. Internal Control-Integrated Framework.

[2] Albert L Nagy, William J Center, An Assessment of the Newly Defined Internal Audit Function, Managerial Auditing Journal, 2002 (17).

[3] Alan Levinsohn, Preparing to Publicize Financial Controls, Strategic Finance, 2003 (7): 61.

[4] Brad Humphrey, Growing your Business through Financial Controls, Concrete Concepts, 2005, (1) 8. 